\title{
International Student's Academic Achievement: Contribution of Gender, Self-efficacy and Socio-cultural Adjustment
}

\author{
Aqeel Khan ${ }^{1}$, Abdul Rahim Hamdan ${ }^{1}$, Roslee Ahmad $^{1} \&$ Mohamed Sharif Mustaffa $^{1}$ \\ ${ }^{1}$ Faculty of Education, Universiti Teknologi Malaysia, Skudai, Johor Bahru, Malaysia \\ Correspondence: Aqeel Khan, Faculty of Education, Universiti Teknologi Malaysia, Skudai 81310 Johor Bahru, \\ Malaysia. E-mail: draqeelkhan@gmail.com
}

Received: September 22, 2014

Accepted: January 20, 2015 Online Published: April 20, 2015

doi:10.5539/ass.v11n10p153

URL: http://dx.doi.org/10.5539/ass.v11n10p153

\begin{abstract}
International students who pursue their education in other country have to cope various challenges related to their adjustment. Successful adjustment to higher learning institution becomes an important issue, failure to which may hinder self-efficacy and their academic achievement. Aim of current research is to investigate the influence of self-efficacy, and socio-cultural adjustment on their academic achievement among International students in Malaysia. Two hundreds International students were randomly selected from the Kuala Lumpur, Out of these 100 belongs to male and 100 belong to female category. The age range of the respondents are 17 to 27 years $(M e a n=20.55)$. Various psychological constructs were used to assess the studied variables. Correlational and regression statistical analysis were applied. Findings reveal significant positive correlation in academic achievement with socio-cultural adjustment and self-efficacy. Gender, self-efficacy and socio-cultural adjustment significantly predicts students' academic achievement. Findings proved gender, self-efficacy and socio-cultural adjustment significantly effecting International student's academic achievement among International students in Malaysia. Implications for International students are significant in terms of countering adjustment problems by developing self-efficacy and cultural values as a result academic achievement may improve.
\end{abstract}

Keywords: socio-cultural adjustment, self-efficacy and academic achievement

\section{Introduction}

Asians valued academic achievement highly as it is perceived as one of the few avenues for upward mobility (Gloria \& Ho, 2003; Sue \& Okazaki, 1990). Not meeting one's own expectations and encouragement is a serious matter which could potentially leads to loss of confidence and support from one's family (Khan, 2012; Yeh \& Huang, 1996). In educational context, existing relationship has been observed between academic achievement and several factors that likely affect success, including motivation, parental involvement (Steinberg, Lamborn, Dornbusch, \& Darling, 1992), encouragement (Evans, 1997), encouragement with respect to education in particular (Catsambis, 1998).

International student's plays significant role in multi-culture based society by delivering various cultures and perception in the host country. Brisset et al. (2010) found that shifting to another country for getting education happening commonly incidence. International students those who decide to do their studies in a overseas country have to cope with their adjustment. Such students need to deal with the changes between culture of their hosts and their own culture (Ang \& Liamputtong, 2008). It has been reported by previous researchers that foreign students go through the process of adjustment to newly developed education set up (Misra et al., 2003). New environment's adjustment could be taxing process (Sumer et al., 2008) for overseas students definitely have the intensified stress for their adjustment to new environment. The school emphasizes systematic, organization of activities which are largely based on achievement and performance so academic achievement considered main norms to justify potential capabilities. In Asian context, parents hope their children will get good grades because it is important in getting a good job. For example, there is an old proverb in Chinese "Everything is unworthy except studying" (cited in Khan, 2012). Therefore, it is demanding for the students to have high academic grades. Researchers have explored the links between variety of factors and academic achievement, such as self-efficacy (Bandura, 1997), cultural expectations (Ginsburg, 1992), and gender (Gibbons, 2000) are likely to influence international students' success. Since Malaysian culture represent diverse multi-ethnic and multi-cultural society (Verkuyten \& Khan, 2012; Janssens et al., 2014). 


\subsection{Self-efficacy and Academic Achievement}

Self-efficacy denotes people's beliefs about their capabilities to produce designated levels of performance, which influence over events that affect their lives (Bandura, 1977). It is believed that person experience greater self-efficacy leads to found greater ambitions (Cited in Khan, 2013), continue in chasing those goals, set even additional aims when previous aims fulfilled, and involve more often in task related actions. Academic achievement refers to the successes and failures met by individuals in their classes-i.e., at school, college or university. Whereas academic development is associated with gradual processes in achievement from year to year, while academic achievement encompasses enhancement, self-actualization and some forms of competitiveness (Maslow \& Murphy, 1954). Existing research has shown that academic achievement is closely linked to self-efficacy (Komarraju \& Nadler, 2013).

\subsection{Gender and Academic Achievement}

Gender variables play an important role, which contribute in Asian's academic achievement (Khan, 2012). Earlier studies proven the presence of different forms in male and female, such as female incline to give higher importance to strengthen achievement (Alshemmeri et al., 2011; Lightbody, Siann, Stocks, \& Walsh, 1996), boys believe higher in skill and furtune as causes of performance (Burgner \& Hewstone, 1993). Relation of academic achievement exists with gender (Fergusson \& Horwood, 1997).

A number of studies have highlighted the positive effects of parental involvement in school experiences and academic affairs (Lee, 1994; Sui-Chu \& Willms, 1996), in the supervision and monitoring of children's academic progress (Astone \& McLanahan, 1991; \& Sui-Chu \& Willms, 1996), and, to a lesser extent, in school-related activities (Epstein, 1992; Sui-Chu \& Willms, 1996) such as parent-teacher conferences (Stevenson \& Baker, 1987). Moreover, parents influence their children's achievement through their direct involvement in schoolrelated activities, such as helping with homework and course selection, as well as through implicitly and explicitly encouraging school success by setting and maintaining high standards. Indeed, considerable research in the tradition of the Wisconsin Status Attainment Model (e.g., Sewell \& Hauser, 1980) has suggested that parental encouragement is the primary mediator of the well-established connection between family social class and student academic achievement. It becomes important to know the issues most comprised in a positive adjustment and how it might influence the students' academic achievement.

Hypothesis 1: There will be positive correlation on international students' self-efficacy, socio-cultural adjustment and academic achievement.

Hypothesis 2: Gender, Social Efficacy and Socio-Cultural Adjustment will be important contributing factor for Academic Achievement.

\section{Method}

\subsection{Sample and Procedure}

Two hundred International students were randomly selected from the public university of Malaysia, from which 100 were boys and 100 were girls, their age varies 17 to 27 years. Before starting collection of data, participant's consent was granted. Respondents were given instructions containing objective of the questionnaire and how to complete the instrument form. Respondents were not allowed to mention their name and respondents were assured by the researchers that their identity will not be disclosed.

\subsection{Instruments}

\subsubsection{Socio Cultural Adaptation Scale}

SCAS prepared by Ward \& Kennedy (1999) with 29 items by means of five-point Likert measure ranged 1 means not difficult to 5 means extreme difficult. Scores found from this measure designated the participants' view once confronting problems of perception of Malaysian morals and cultural values (Hamdan et al., 2014; Ghani et al., 2014). Example instrument questions comprised declarations like "Understanding jokes and humors" etc. This instrument encompasses in 2 separate elements. First element covers respondents' Behavioural Adaptation Difficulty consists of twenty two questions and the other part measures the Cognitive-Adaptation Difficulty with 7 items. Greater values obtained in the scale declared higher difficulty in socio-cultural adaptation. In the current study, the overall reliability of the scale was established excellent $(\alpha=.95)$; the 7 -items cognitive-adaptation difficulty $(\alpha=.93)$ and the twenty two items on behavioural-adaptation difficulty $(\alpha=.97)$ were found reliability excellent.

\subsubsection{Cross-cultural Social-efficacy}

CCSE developed by (Fan \& Mak, 1998) were used to measure cross-cultural social-efficacy of students 
responded to a seven-point instrument ranged 1 means strongly agree to seven means strongly disagree. Example questions consist like "I feel confident asking a lecturer a question" etc. This scale consists of 20-items with four subscales: Absence of Social Difficulties, Sharing Interests, Friendship Initiative and Social Confidence. Each subscale can be calculated separately. The overall scale's reliability was .89 in the current research, researchers found Cronbach alpha reliability of $.96, .85, .94$, and .92 indicate reliability for subscales respectively.

\subsubsection{Academic Achievement}

The dependent variable was the students' academic achievement based on students' academic CGPA.

\subsection{Data Analysis}

Data were analyzed by correlational and regression analysis using spss 17 version.

\section{Results}

Table 1. Mean, cronbach's alpha, correlations of dimensions of social efficacy, socio-cultural adjustment and academic achievement

\begin{tabular}{|c|c|c|c|c|c|c|c|c|c|c|c|}
\hline Variables & $\mathbf{M}$ & $\boldsymbol{\alpha}$ & 1 & 2 & 3 & 4 & 5 & 6 & 7 & 8 & 9 \\
\hline $\begin{array}{l}\text { Behavioral Adaptation Difficulty } \\
\text { (1) }\end{array}$ & 4.55 & .96 & 1 & & & & & & & & \\
\hline $\begin{array}{l}\text { Cognitive-Adaptation } \\
\text { Difficulty (2) }\end{array}$ & 4.67 & .94 & $.62 * *$ & 1 & & & & & & & \\
\hline Social efficacy (3) & 5.36 & .97 & $.52 * *$ & $.51 * *$ & 1 & & & & & & \\
\hline Absence of Social Difficulties (4) & 5.39 & 96 & $.49 * *$ & $.54 * *$ & $.75^{* *}$ & 1 & & & & & \\
\hline Social Confidence (5) & 5.12 & .85 & $.56^{* *}$ & $.59 * *$ & $.61 * *$ & $.79 * *$ & 1 & & & & \\
\hline Sharing Interests (6) & 8.28 & .94 & $.32 * *$ & $.31 * *$ & $.23 *$ & $.25 *$ & $.24 *$ & 1 & & & \\
\hline Friendship Initiative (7) & 7.98 & .92 & $.67 * *$ & $.84^{* *}$ & $.32 *$ & $.71 * *$ & $.41^{*}$ & $.23 *$ & 1 & & \\
\hline Socio-cultural adjustment (8) & 7.61 & .85 & $.33 * *$ & $.32 * *$ & $.23 *$ & $.25^{*}$ & $.24 *$ & $.24 *$ & $.22 *$ & 1 & \\
\hline Academic Achievement (9) & 4.65 & .89 & $.77 * *$ & $.94 * *$ & $.22 *$ & $.74 * *$ & $.43 *$ & $.28 *$ & $.34 *$ & $.33 *$ & 1 \\
\hline
\end{tabular}

$* \mathbf{p}<.05 * * \mathbf{p}<.01$

Table 2. Predictor variables gender, self-efficacy and socio-cultural adjustment

\begin{tabular}{lllll}
\hline Model & $\beta$ & SEM & $t$ & $p$ \\
\hline Construct & 3.401 & .326 & 10.431 & $.000^{*}$ \\
Gender & .631 & .018 & -3.19 & $.000^{*}$ \\
Self-efficacy & .055 & .017 & -3.148 & .002 \\
Socio-cultural Adjustment & .349 & .039 & -3.79 & .000 \\
\hline
\end{tabular}

Dependent variable is Academic Achievement

R-Square: .282

\section{Discussion}

Table 1 Reported Pearson correlations between variables tabulated in a matrix shows positive correlations between same variables were perfect. Higher self-efficacy, socio-cultural adjustment correlate with higher academic achievement, evidence says self-efficacy was linked with self-regulation, cognitive abilities, adjustment and motivation (Paunonen \& Hong, 2010; Zajacova et al., 2005). Academic achievement was linked with motivation and socially responsibleness (Patrick et al., 1997). On the basis of Bandura's (1977) self-efficacy theoretical concept, cross-cultural self-efficacy is a valuable contributing factor for socio-cultural adjustment.

Table 2 Representing regression results for gender, social efficacy and socio-cultural adjustment, which present an important result on the academic achievement in the international student's. The gender was showing the best predictor for academic achievement for the international students. R square demonstrating predictor's variables i.e., Gender, self-efficacy and socio-cultural adjustment were contributed $28.2 \%$ in the academic achievement. It is believed that students extremely socially anxious incline to diminish their shared performance (Clark \& Wells, 
1995). Asonibare and Olayonu (1997); Bandura (1986, 1997); Khan et al. (2014) endorsed that self-efficacy predict students' academic achievement.

High efficacy develops ability to cope with life challenges (Khan \& Husain, 2012) and help to counter academic situations and problems, which intern improve their adjustment problems and academic success (Poyrazli et al., 2002). International students, as they express shared in addition to their exclusive difficulties like ethnic bias, linguistic problems, household difficulties, economic strain, confusions, and isolations (Lin \& Yi, 1997). Moreover, belong to dissimilar culture of overseas students could not escape from culture shock and in facing frequent difficulties (Oudenhoven \& Zee, 2002; Pruitt, 1978). Current research suggests higher self-efficacy considered to be contributing factor for successful adjustment of International students, as they considered important role in making culturally diverse society. As a result of their successful adjustment in university setting in turn may possibly improve their academic achievement.

Educational encouragement represents one potentially influential factor, and a substantial body of research has examined the influence of encouragement on academic achievement. Dreikurs (1971) has regarded the ability to encourage a child as the most important element in raising a child in a democracy. Experiences with receiving encouragement are important contributors to the ability to interact successfully in both personal and professional domains (Dinkmeyer \& Losoncy, 1996). Evans (2005) described encouragement as positive feedback directed primarily at the effort or improvement demonstrated by an individual, rather than at the outcome per se; this process-over-content focus promotes self-worth, irrespective of the actual results of a particular endeavor.

\section{Conclusion}

Overall finding suggests International students confidence helps them to motivate in higher educational aspirations and academic achievement. Our study demonstrated there is factors influence on International student's adjustment, as an intervention university may offer International students support services like mentoring and counseling programs (Khan et al., 2014; Khan \& Kalu, 2011) for better adjustment in Malaysian society and culture to international students, as a result their adjustment difficulties may reduce.

\section{Acknowledgements}

Author would like to thanks to Universiti Teknologi Malaysia (UTM) for providing financial support for this study.

\section{References}

Alshemmeri, F., Putih, A., Siraj, S., Khan, A., \& Abdallah, N. (2011). Art Ability and Academic Achievement in the Kingdom of Saudi Arabia: Role of Age and Sex. New Educational Review, 26(4), 238-247.

Ang, P. L. D., \& Liamputtong, P. (2008). "Out of the circle": Reflection on conducting research into the views of international students from mainland China towards the use of university counselling services. Journal of Australian and New Zealand Student Services Association, 30, 6-26.

Asonibare, J. B., \& Olayonu, E. U. (1997). Locus of control, personality type and academic achievement of secondary school students of Offa and Ayun Local Government Areas. Nigerian Journal of Clinical and Counseling Psychology, 3, 14-23.

Astone, N. M., \& McLanahan, S. S. (1991). Family structure, parental practices, and high school completion. American Sociological Review, 56, 309-320. http://dx.doi.org/10.2307/2096106

Bandura, A. (1986). Social foundations of thought and action: A social cognitive theory. Engelwood Cliffs, NJ: Prentice Hall.

Bandura, A. (1997). Self-efficacy: The exercise of control. New York: W.H. Freeman and Company.

Brisset, C., Safdar, S., Lewis, J. R., \& Sabatier, C. (2010). Psychological and sociocultural adaptation of university students in France: The case of Vietnamese international students. International Journal of Intercultural Relations, 34, 413-426. http://dx.doi.org/10.1016/j.ijintrel.2010.02.009

Burgner, D., \& Hewstone, M. (1993). Young children's causal attributions for success and failure: "Self-enhancing boys" and "self-derogating girls". British Journal of Developmental Psychology, 11, 125-129. http://dx.doi.org/10.1111/j.2044-835X.1993.tb00592.x

Catsambis, S. (1998). Expanding knowledge of parental involvement in secondary education. Retrieved December 6, 2005, from http://www.csos.jhu.edu/crespar/techRepofisRepofi27.pdf 
Clark, D. M., \& Wells, A. (1995). A cognitive model of social phobia. In R. Heimberg, M. Liebowitz, D. A. Hope, \& F. R. Schneier (Eds.), Social phobia: Diagnosis, assessment and treatment (pp. 69-93). New York: Guilford Press.

Dinkmeyer, D., \& Losoncy, L. (1996). The skills of encouragement. Delray Beach, FL: St. Lucie Press.

Dreikurs, R. (1971). Social equality. Chicago: Alfred Adler Institute.

Epstein, J. L. (1992). School and Family Partnerships. In M. Alkin (Ed.), Encyclopedia of educational research (6th ed.). New York: MacMillan.

Evans, T. (2005). The tools of encouragement. The International Child and Youth Care Network (Vol. 73). Retrieved from http://www.cyc-net.org/cyc-online/cycol-0205-encouragement.html

Fan, C., \& Mak, A. S. (1998). Measuring social self-efficacy in a culturally diverse student population. Social Behaviour and Personality, 26, 131-144. http://dx.doi.org/10.2224/sbp.1998.26.2.131

Fergusson, D. M., \& Horwood, L. J. (1997). Gender differences in educational achievement in a New Zealand birth cohort. New Zealand Journal of Educational Studies, 32(1), 83-96.

Ghani, F. A., Latif, A. A., Aziz, A. A., \& Khan, A. (2014). Validity and Reliability Analysis of the 'Sayang KU' (MyLove) in Intervention for Addressing Adolescents Involved in Free Sex. Journal of Religion and Health. http://dx.doi.org/10.1007/s10943-014-9935-y

Gibbson, J. L. (2000). Gender development in cross-cultural perspective. In T. Eckes, \& H. M. Trautner (Eds.), The developmental social psychology of gender. Mahwah, NJ: Erlbaum.

Gloria, A. M., \& Ho, T. A. (2003). Environmental, social, and psychological experiences of Asian-American undergraduates: Examining issues of academic persistence. Counseling and Development, 81, 93-106. http://dx.doi.org/10.1002/j.1556-6678.2003.tb00230.x

Hamdan, A. R., \& Kwan, C. R., \& Khan, A., Ghafar, M. N. A., \& Sihes, A. J. (2014). Implementation of Problem Based Learning among Nursing Students. International Education Studies, 7(7), 136-142. http://dx.doi.org/ 10.5539/ies.v7n7p136

Janssens, H., Verkuyten, M., \& Khan, A. (2014). Perceived social structural relations and group stereotypes: A test of the Stereotype Content Model in Malaysia. Asian Journal of Social Psychology. http://dx.doi. org/10.1111/ajsp.12077

Jex, S. M., \& Britt, T. W. (2008). Organizational psychology: A scientist-practitioner approach (2nd ed.). New York: John Wiley and Sons.

Khan, A. (2012). Sex Differences' in Educational Encouragement and Academic Achievement. Psychological Reports, 111(1), 149-155. http://dx.doi.org/10.2466/10.11.21.PR0.111.4.149-155

Khan, A. (2013). Predictors of Positive Psychological Strengths and Subjective Well-being among North Indian Adolescents: Role of Mentoring and Educational Encouragement. Social Indicators Research, 114(3), 1285-1293. http://dx.doi.org/10.1007/s11205-012-0202-x

Khan, A., \& Husain, A. (2010). Social Support as a Moderator of Positive Psychological Strengths and Subjective Well-Being. Psychological Reports, 106, 534-538. http://dx.doi.org/10.2466/pr0.106.2.534-538

Khan, A., \& Kalu, O. C. (2011). Psychology and counselling responsibilities for continuous assessment in Malaysian school system. Scientific Research and Essays, 6(11), 2259-2263.

Khan, A., Ahmad, R., Hamdan, R. A., \& Mustaffa, M. S. (2014). Educational Encouragement, Parenting styles, Gender and Ethnicity as Predictors of Academic Achievement among Special Education Children. International Education Studies, 7(2), 18-24. http://dx.doi.org/10.5539/ies.v7n2p18

Khan, A., Hamdan, R. A., Ahmad, R., \& Mustaffa, M. S. (2014). Mentoring in Indian Youth Challenges. Man in India, 94(1-2), 265-269.

Komarraju, M., \& Nadler, D. (2013). Self-efficacy and academic achievement: Why do implicit beliefs, goals, and effort regulation matter? Learning and Individual Differences, 25, 67-72. http://dx.doi.org/10.1016/j. lindif.2013.01.005

Lee, S. (1994). Family-school connections and student's education: Continuity and change of family involvement from the middle grades to high school. Doctoral dissertation, Johns Hopkins University, Baltimore, MD.

Li, A., \& Gasser, M. B. (2005). Predicting Asian international students' sociocultural adjustment: A test of two mediation models. International Journal of Intercultural Relations, 29, 561-576. http://dx.doi.org/10. 1016/j.ijintrel.2005.06.003 
Lightbody, P., Siann, G., Stocks, R., \& Walsh, D. (1996). Motivation and attribution at secondary school: The role of gender. Educational Studies, 22, 13-25. http://dx.doi.org/10.1080/0305569960220102

Lin, J. C. G., \& Yi, J. K. (1997). Asian international student's adjustment: Issues and program suggestions. College Student Journal, 31, 473-480.

Maslow, A., \& Murphy, G. (1954). Motivation and Personality. New York: Harper.

Misra, R., Crist, M., \& Burant, C. J. (2003). Relationship among life stress, social support, academic stressors, and reactions to stressors of international students in the United States. International Journal of Stress Management, 10, 137-157. http://dx.doi.org/10.1037/1072-5245.10.2.137

Patrick, H., Hicks, L., \& Ryan, A. M. (1997). Relations of perceived social efficacy and social goal pursuit to self-efficacy for academic work. Journal of Early Adolescence, 17(2), 109-128. http://dx.doi.org/10.1177 /0272431697017002001

Paunonen, S. V., \& Hong, R. Y. (2010). Self-efficacy and the prediction of domain specific cognitive abilities. Journal of Personality, 78, 339-360. http://dx.doi.org/10.1111/j.1467-6494.2009.00618.x

Poyrazli, S., Arbona, C., Nora, A., McPherson, R., \& Pisecco, S. (2002). Relation between assertiveness, academic self-efficacy, and psychosocial adjustment among international graduate students. Journal of College Student Development, 43, 632-643.

Pruitt, F. J. (1978). The adaptation of foreign students on American campuses. Journal of the National Association for Women Deans, Administrators and Counselors, 41, 144-147.

Sewell, W., \& Hauser, R. (1980). The Wisconsin longitudinal study of social and psychological factors in aspirations and achievements. In A. Kerckhoff (Ed.), Research in the sociology of education and socialization (Vol. 1, pp. 59-100). Greenwich, CT: JAI.

Steinberg, L., Lamborn, S., Dornbusch, S., \& Darling, N. (1992). Impact of parenting practices on adolescent achievement: authoritative parenting, school involvement, and encouragement to succeed. Child Development, 63, 1266-1281. http://dx.doi.org/10.2307/1131532

Stevenson, D.L. \& Baker, D.P. (1987). Family-school relation and the child's school performance. Child Development, 58, 1348-1357. http://dx.doi.org/10.2307/1130626

Sue, S., \& Okazaki, S. (1990). Asian-American educational achievements: A phenomenon in search of an explanation. American Psychology, 45, 913-920. http://dx.doi.org/10.1037/0003-066X.45.8.913

Sui-Chu, H. E., \& Willms, J. D. (1996). Effects of parental involvement on eighth grade achievement. Sociology of Education, 69, 126-141. http://dx.doi.org/10.2307/2112802

Sumer, S., Poyrazli, S., \& Grahame, K. (2008). Predictors of depression and anxiety among international students. Journal of Counselling and Development, 86, 429-437. http://dx.doi.org/10.1002/j.1556-6678. 2008.tb00531.x

Van Oudenhoven, J. P., \& Van der Zee, K. I. (2002). Predicting multicultural effectiveness of international students: the Multicultural Personality Questionnaire. International Journal of Intercultural Relations, 26 , 679-694. http://dx.doi.org/10.1016/S0147-1767(02)00041-X

Verkuyten, M., \& Khan, A. (2012). Interethnic relations in Malaysia: Group identifications, indispensability and inclusive nationhood. Asian Journal of Social Psychology, 15(2), 132-139. http://dx.doi.org/10.1111/j.1467839X.2012.01374.x

Ward, C., \& Kennedy, A. (1999). The measurement of sociocultural adaptation. International Journal of Intercultural Relations, 23, 659-677. http://dx.doi.org/10.1016/S0147-1767(99)00014-0

Yeh, C. J., \& Huang, K. (1996). The collectivistic nature of ethnic identity development among Asian-American college students. Adolescence, 31, 645-662.

Zajacova, A., Lynch, S. M., \& Espenshade, T. J. (2005). Self-efficacy, stress, and academic success in college. Research in Higher Education, 46, 677-706. http://dx.doi.org/10.1007/s11162-004-4139-z

\section{Copyrights}

Copyright for this article is retained by the author(s), with first publication rights granted to the journal.

This is an open-access article distributed under the terms and conditions of the Creative Commons Attribution license (http://creativecommons.org/licenses/by/3.0/). 